Article

\title{
Community-Led Green Land Acquisition: Social Innovative Initiatives for Forest Protection and Regional Development
}

\author{
Karina Castro-Arce ${ }^{1,2, *(D)}$ and Frank Vanclay ${ }^{2}$ (D) \\ 1 School of Architecture, University of Costa Rica, Montes de Oca 11501, Costa Rica \\ 2 Urban and Regional Studies Institute, Faculty of Spatial Sciences, University of Groningen, \\ 9700AV Groningen, The Netherlands; frank.vanclay@rug.nl \\ * Correspondence: karina.castro@ucr.ac.cr
}

Received: 29 February 2020; Accepted: 2 April 2020; Published: 4 April 2020

check for updates

\begin{abstract}
Land acquisition often involves power and displacement and can be carried out on a large scale. There are many forms of land acquisition, including for environmental and conservation purposes as well as for production activities. While green grabbing has joined land grabbing as an environmental justice issue of concern, it is not necessarily the case that all green land acquisition is large scale, done by powerful outsiders, or leads to displacement and exclusion. The outcomes of green land acquisition are dependent on the mechanisms used, the adequacy of resettlement and/or compensation, and the social and environmental context in which it happens. We discuss the outcomes of community-led land acquisition for conservation purposes in Costa Rica. We considered a special case of green land acquisition done by local civil society to defend the forest and water resources of the Juan Castro Blanco National Water Park in Costa Rica. We used the literature on green grabbing, social ecological systems, and social innovation to discuss local environmental governance and regional sustainable development. This paper makes a fresh contribution to environmental planning and environmental governance by bringing in aspects of green land acquisition that have not been previously explored.
\end{abstract}

Keywords: environmental planning; environmental governance; land grabbing; green grabbing; sustainable regional planning; protected area management; land use management; social innovation; social-ecological systems

\section{Introduction}

Green land acquisition is the process of acquiring land for environmental, conservation or biodiversity preservation purposes [1,2]. Often this involves the exercise of power, displacement, dispossession and exclusion in the accumulation of large tracts of land by governments, transnational corporations, NGOs, or (conservation) trust funds [2]. It usually involves the taking of land from local communities, creating considerable social harm and tends to be called "green grabbing" [3-8]. However, green land acquisition is not necessarily always done by powerful outsiders or inevitably leads to dispossession and disenfranchisement [9]. Various scholars $[1,3,9,10]$ have noted that the outcomes from land acquisition are related to the acquisition process used (e.g., expropriation, negotiated agreement, or "willing buyer, willing seller"), the effectiveness of any resettlement actions, and the geographical, historical, political, socio-economic and environmental context in which the acquisition takes place.

Potentially, various shades of green can be conceived when appraising green land acquisition $[2,11]$. For example, Franco and Borras [12] discussed the subtle interconnections between climate change 
politics and green grabbing, pointing out the role of governance, local institutions, and domestic corporate actors. Sikor [13] and Dao [14] exemplified that considerable land acquisition for rubber plantations in Vietnam was done by local farmers with the support of national development programs. In Indonesia, Pasaribu et al. [15] identified that local villages were often in favor of forestry and palm oil plantations because of the job opportunities and community social investment programs implemented by the plantation companies. Holmes [16] explored green grabbing by looking at the relations between private protected areas, nature conservation and resource exploitation in Chile. $\mathrm{Xu}$ [17] exposed the negative consequences of small-scale land acquisition by villagers for farming in China.

In this paper, we explore green land acquisition by using a social innovation lens. We contribute to the green grabbing and land acquisition literature by considering a special case of small-scale green land acquisition done by local civil society in and around a protected area (PA), the Juan Castro Blanco National Water Park in Costa Rica. In general terms, we considered situations where land acquisition for environmental purposes was positive, not only for conservation purposes but also for regional development and local wellbeing. We argue that such local actions are examples of social innovation.

Social innovation can be defined as "the creation, renewal or transformation of social relations in the development of new ways of working together to achieve societal goals" [18] (p. 2). Social innovation occurs when there is a need to address important social and/or social-ecological matters. This means that social innovation is fundamentally a normative concept: it seeks the improvement of community wellbeing, usually but not always the marginalized or those with limited power and resources [18]. As Moulaert et al. [19] (p. 7) emphasized, social innovation "means fostering inclusion and wellbeing through improving social relations and empowerment processes". In environmental governance scholarship, social innovation is regarded as critical to achieving sustainability and fostering the resilience of social-ecological systems (SES) [20-22]. Mehmood \& Parra [23] argued that social innovation connects all sustainability pillars and consequently better conceptualizes and fosters sustainable development. Similarly, Biggs et al. [24] considered social innovation to be a way of developing more adaptive, integrated ecosystem management practices to improve society's ability to sustainably manage complex social-ecological systems.

Social innovation has been applied as a useful concept to examine the social-ecological enhancement of regions [18], protected areas [25], Indigenous reserves [26], forests and other natural resource territories [27-30]. Despite these examples, social innovation has not been used to analyze green land acquisition. The purpose of our paper is to contribute to an enhanced understanding of social innovation, by focusing on the motivations for and mechanisms to implement green land acquisition.

\section{Methods}

The information presented here is part of a comprehensive qualitative research project about social-ecological regional planning in Costa Rica $[18,25]$. For this paper, we used case study research methods [31,32] to explore two community-based organizations (CBOs) that developed social innovation mechanisms to purchase land for conservation purposes in and around the Juan-Castro-Blanco National Water Park. These organisations were the Association for the Protection of the Juan-Castro-Blanco National Water Park (APANAJUCA) and the Association Source Manager of the Aquifers of the Municipality of Alfaro Ruiz (AFAMAAR). Fieldwork was conducted in 2015, with a follow-up in 2019. Given our multiple data sources, we used triangulation to validate information and to crosscheck the theoretical construction with data interpretation.

Consistent with case study research, multiple research methods were used. First, a total of 39 people were interviewed using semi-structured interviews regarding the governance of the Juan-Castro-Blanco National Water Park and local environmental planning processes. The interviewees were selected using a snowball sampling technique. The interviews were conducted in Spanish and were audio-recorded so that they could be played-back later. Extensive notes were taken during interviews. Formal informed consent was obtained for all interviews, and other principles of ethical social research were observed [33]. Interviewees included key actors from the two community organizations that were 
the primary subject of this research, as well as representatives of cooperatives, NGOs, neighboring landholders, local producers, municipalities, academics, and the Ministry of Environment and Energy (MINAE). Second, by invitation, the lead author attended a range of formal meetings between key actors, during which notes were taken (with consent of those present). Third, fieldwork research was undertaken, including hiking in the park and visits to local communities accompanied by actors associated with the PA, with observations being recorded in a research diary. In advance of the field visits, notes were written to guide the observations. The purpose of using observation was to see the governance dynamics at play, comprehend the spatial outcomes from the CBO's actions, and assess the social-ecological relations within the Juan-Castro-Blanco. Fourth, archival, legal and other relevant documents and on-line resources relating to the park and the CBOs were analyzed. Fifth, we also analyzed quantitative data from cartographic and geographic information systems provided by the municipalities of San Carlos and Zarcero, and other sources.

\section{Description of the Case Study}

The Juan-Castro-Blanco National Water Park, which was created in 1968, is a PA located between the northern region (Huetar) and the central region of Costa Rica (see Figure 1). This PA now comprises 14,500 hectares and has a Protected Area Category II rating. It was designated as a freshwater protected area in 2003 in recognition of the importance of its water resources [34]. This park is of high importance biologically and socially and provides essential ecosystem services (see Figure 2). More than 50 rivers have their source in the park [35]. The park's freshwater directly benefits 150 communities in four municipalities in terms of: potable water distributed by local water supply organizations; crop irrigation and water for cattle raising; electricity from 10 hydroelectric power plants; and tourism. The park provides an average of 996 million cubic meters of water annually; produces $17 \%$ of national electricity generation; and $12 \%$ of national milk production comes from within or around the park [35,36].

Despite considerable achievements in conservation and sustainability [37-39], Costa Rica cannot afford to adequately protect all its PAs, biodiversity and natural resources [40]. Protected areas are a demarcated geographical area, officially declared and designated, that have natural, cultural and/or socio-economic importance, and are intended to achieve certain conservation and management objectives [41]. As a mechanism to address its lack of economic resources, when a PA is declared, rather than immediately acquire all land (as is often done elsewhere in the world), the Costa Rican government allows current landowners to remain but imposes controls on their land use activities, with the land potentially being expropriated and compensation paid in due course. Therefore, most land within Costa Rica's PAs is privately owned. The Juan-Castro-Blanco National Water Park is a significant example of this; $92 \%$ of its area is under private ownership.

Consolidation of the park's land and protection of its freshwater resources have been the primary purpose of two not-for-profit CBOs: APANAJUCA and AFAMAAR. These organisations work independently but have similar goals, each on one side of the watershed. With members working voluntarily, both CBOs have developed socially innovative mechanisms for green land acquisition which we argue are interesting to document and discuss. 


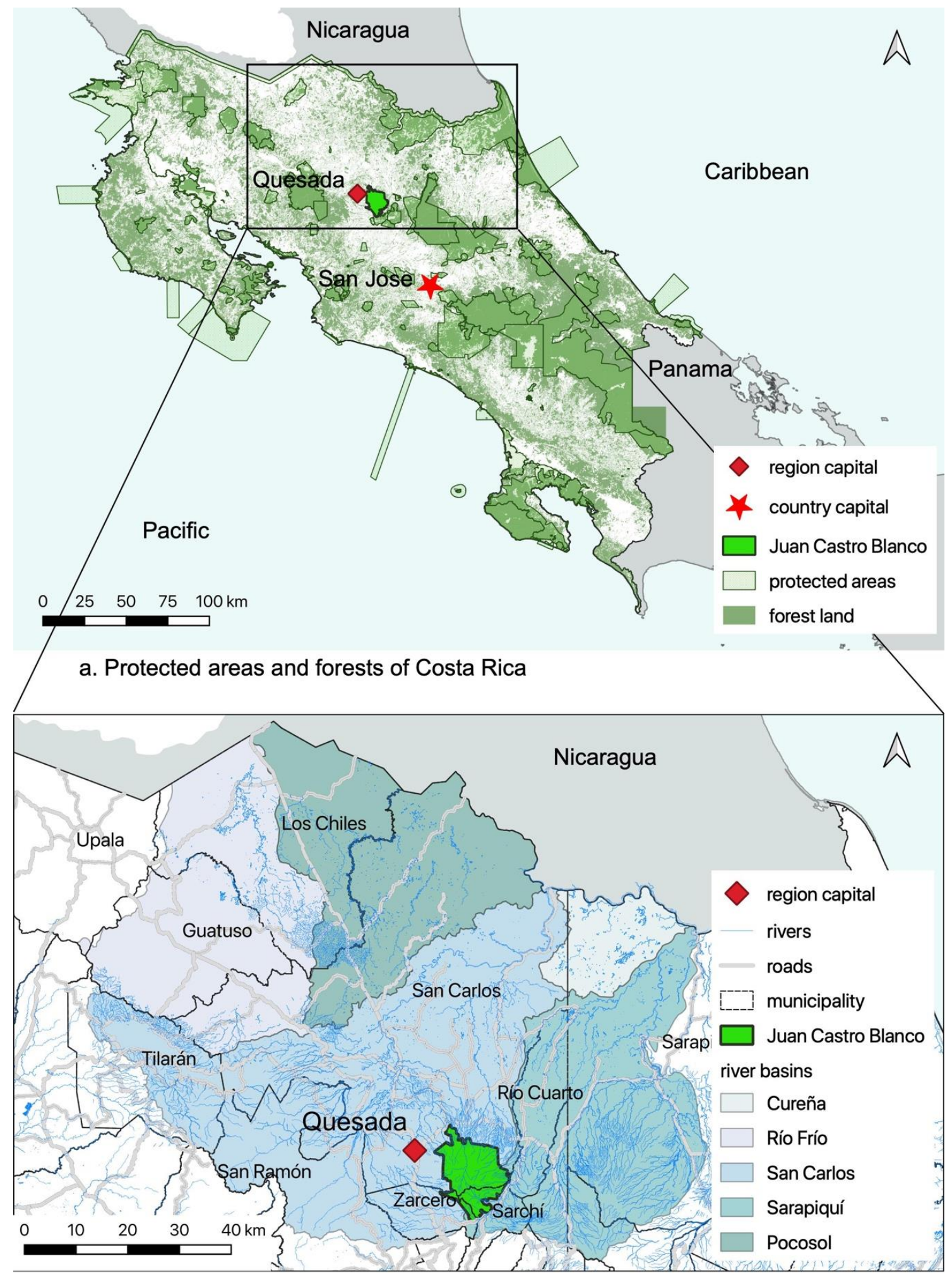

b. Hydrological importance of the Juan Castro Blanco National Water Park

Figure 1. Location of the Juan-Castro-Blanco National Water Park. (a) Protected areas and forest in Costa Rica, data from year 2017. (b) Hydrological importance of the park. Source: author, based on geographical information data available at Registro Nacional, 2020. 


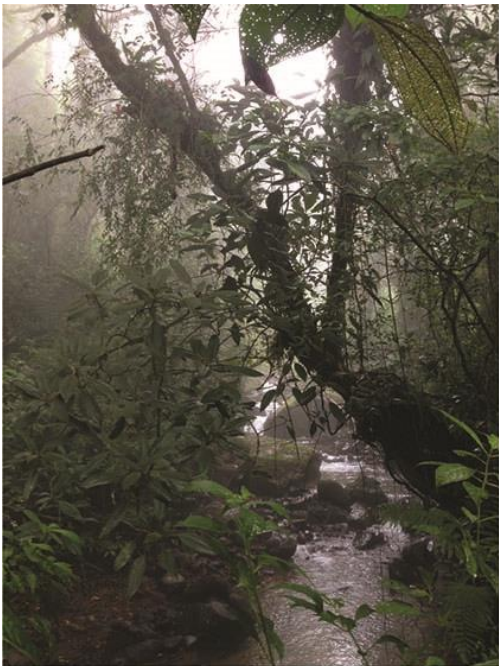

a. La Vieja river origin

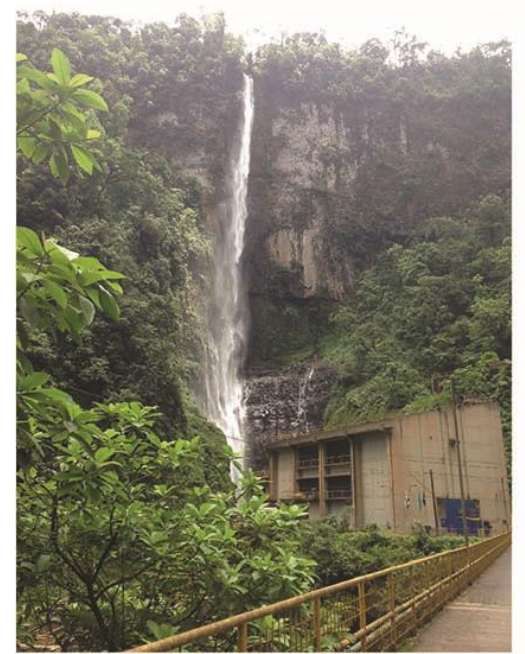

c. Toro III hydroelectric project

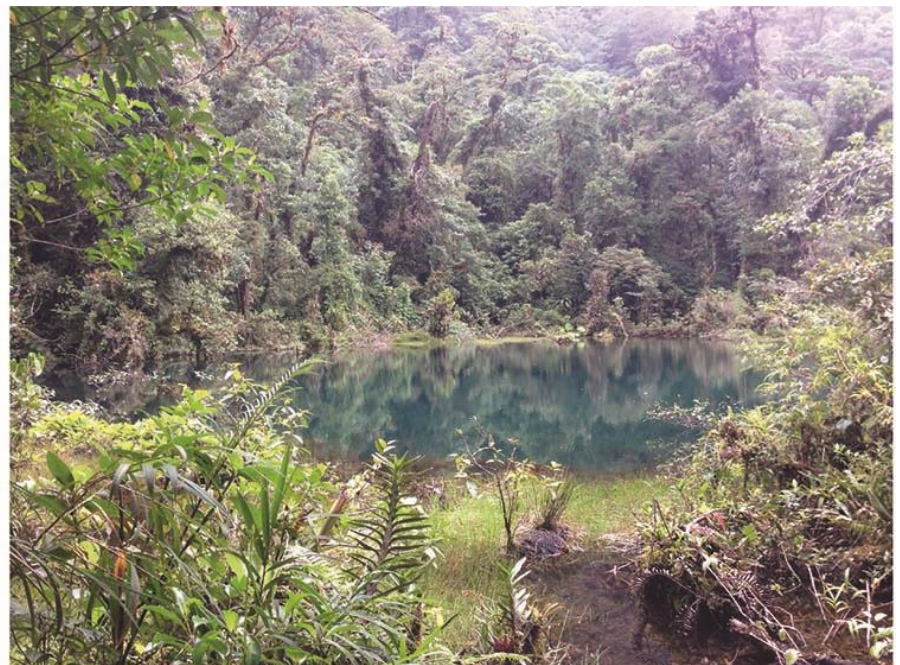

b. Pozo Verde lagoon

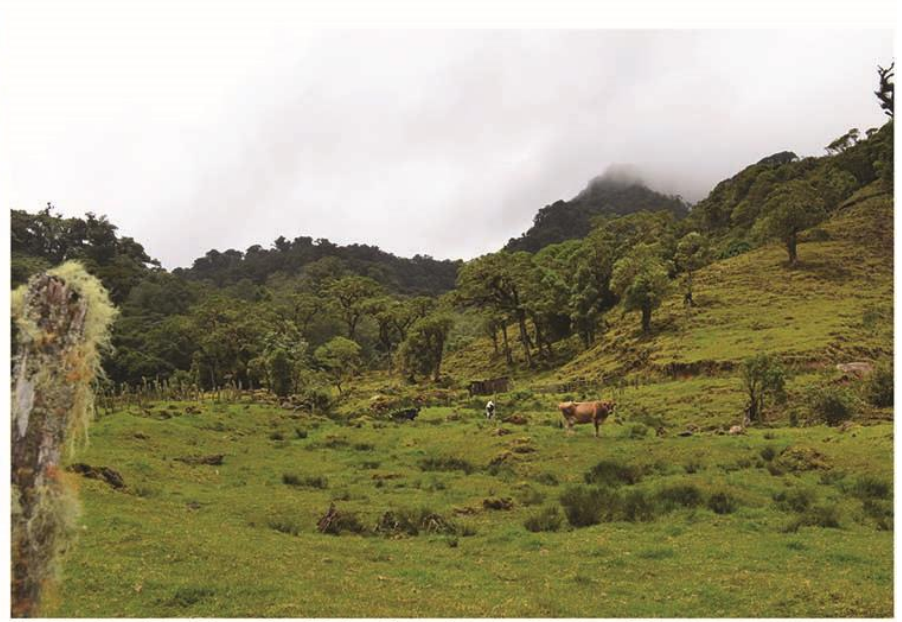

d. Dairy farmland within the Juan Castro Blanco

Figure 2. Some of Juan-Castro-Blanco National Water Park features. (a) La Vieja river origin. (b) Pozo Verde lagoon. (c) Toro III hydroelectric project, ICE. (d) Dairy farmland within the park's lands. Source: author.

\section{Community-Based Organizations and Demands for Sustainability}

Protected areas are key for the conservation of tropical forests; yet it is estimated that less than $10 \%$ of the world's remaining tropical forests are within PAs [42]. They are easily disturbed by human actions occurring within their boundaries and in surrounding areas. The period between 1980 and 2000 experienced a major shift in land use in the world in which more than $80 \%$ of new agricultural land came from tropical forests rather than previously cleared lands [43]. Costa Rica is one of the few countries in the world that has an increase in forest cover, going from $26 \%$ in 1983 to over $52 \%$ in 2013 . It also has a high percentage (over 26\%) of protected land, with more than 190 PAs [44-46]. However, its forests and PAs are not exempt from the environmental management issues that affect tropical forests generally. Gonzalez-Maya et al. [46] determined that, despite the amount of land set aside for PAs in Costa Rica, many species-rich areas were still not protected. Of particular concern is that there is a lack of effective environmental management in the periphery areas of PAs [47]. Duffy et al. [48] confirmed that farmers in Costa Rica still convert land, particularly forests, for agricultural land use. 
A World Bank [45] report highlighted that Costa Rica has historically underestimated the value of its forests, and that it is crucial to adjust forest and forestry policies to effectively protect these resources and ecosystem services. These general issues are also experienced in the Juan-Castro-Blanco National Water Park and surroundings. Being conscious of these issues led the two CBOs researched for this paper to establish their purpose and strategies.

\subsection{APANAJUCA: The Association for the Protection of the Juan-Castro-Blanco National Water Park}

The Association for the Protection of the Juan-Castro-Blanco National Water Park was created in 1998 by citizens of the San Carlos municipality as an association dedicated to representing the park's interests and to advocating for the park's role in regional sustainable development [18]. The members of APANAJUCA were from communities close to the park and the nearby regional centre, Quesada. They belong to various sectors, including dairy production, tourism, cooperatives, commerce, service, energy, public organizations, and the Catholic Church.

The concern of APANAJUCA is to preserve water for future generations, and this interest is shared not only by neighbouring communities but also by local public institutions and private companies. The interviewees claimed that there was a clear awareness in APANAJUCA and the civil society of Quesada in general of the importance of the ecosystem services the park provides, especially those related to water resources (e.g., hydroelectricity, drinking water, hot springs and other nature tourism attractions, good farming soils and biodiversity). However, they recognised that the park has been in constant risk from public policies and private interests. For example, in 1989, the Costa Rican national government granted a sulphur mining concession inside the park, and it was only by pressure imposed by the citizens who are now part of APANAJUCA that the concession was cancelled and the Protected Area Category of the park was increased [25]. There have been recent claims about illegal practices within the park such as logging, hunting, and water extraction [49-52]. Another threat to the park is actions by some farmers near the park. For example, in 2019, a group of farmers publicly rebuked the park by deliberately violated the restrictions on their land use. They also took legal action against the State claiming that, because there had been no expropriation of land (or compensation paid) since 1992 (when the park gained Protected Area Category II status), the restrictions on their use of the land were unconstitutional. Although the court eventually ruled otherwise (i.e., that the restrictions were legitimate), in the interim much damage was done [53].

\subsection{AFAMAAR: The Association Source Manager of the Aquifers of the Municipality of Alfaro Ruiz}

The Association Source Manager of the Aquifers of the Municipality of Alfaro Ruiz was created in 1996 by citizens of what is now the Municipality of Zarcero (which was previously known as Alfaro Ruiz). Its purpose is to ensure clean water for human consumption and the availability of water for agricultural purposes. The members of AFAMAAR belong to communities located within the Juan-Castro-Blanco periphery, all being in the agriculture and dairy sector. Initially, this CBO worked under the auspices of the Municipality, but over time it decided to become independent and develop their own structure.

The AFAMAAR was influenced by the Union of Costa Rican Small Agricultural Producers (UPANACIONAL), which had been alerted by health authorities in the 1990s about the high rate of gastric cancer in Zarcero. Following a review of farming practices, UPANACIONAL concluded that, most likely, the municipal water supply was being polluted by agrochemicals. According to interviewees, controls over activities in the buffer zone of water springs were lax. For springs used for human consumption, the 1972 Water Law imposed a buffer (of 100 or $200 \mathrm{~m}$ depending on the context) in which all human activities were prohibited. Although this law was reinforced by the Forestry Law in 1996 which protected all water springs, there has been a lack of enforcement and thus much violation of these restrictions [54,55]. Some local farmers started a campaign to raise awareness of the importance of protecting the forests and water springs from pollution. Local farmers realised early on that what they needed to do was to promote the acquisition of significant land that protected the water 
and forest. This has been their mission for over 20 years. They originally worked under the auspices of the Municipality, raising funds to buy land to set aside as a public asset. Later, it was decided that the group should continue as an independent CBO. The AFAMAAR's goal is to consolidate land in the periphery of the Juan-Castro-Blanco National Water Park where most of the water springs are located, thus protecting the springs and the park.

\section{Socially Innovative Mechanisms for Green Land Acquisition}

Social-ecological systems are complex intertwined systems that encompass social (human) and ecological (nature) components that have reciprocal feedback mechanisms and an interdependent relationship [56-58]. Protected areas are SESs [59]. In an SES, the governance system and actors-users, mediators, and external participants-are intertwined at multiple levels and scales, with decision-making and actions having effects across scales, levels and ecosystems [57,60,61]. Social innovation is part of the social dynamics that foster transformations in ecosystem governance and in the ecosystem itself [24]. Social innovation is as a process, a product, and an outcome, all being intrinsically connected $[18,62]$. Below, we describe the social innovation mechanisms used by APANAJUCA and AFAMAAR for green land acquisition and forest conservation.

\subsection{APANAJUCA and the Coopelesca Scheme}

According to the members of APANAJUCA who were interviewed, in their discussions about the urgency of land consolidation for protection of the Juan-Castro-Blanco National Water Park, one thing was clear: they did not want to become landowners. They considered that their role was to be the voice of the park and to be its protector but not a party with a direct vested interest which they would become if they would own land. They were convinced that all farming and other productive activities that hinder forest rehabilitation and water production should be removed from within the park's boundaries. They also believed it would be easier for the formal management agency of the Huetar North region (ACAHN-SINAC) to supervise and control fewer landowners; and to eventually formally acquire all the land. After careful consideration and many brainstorming sessions with its members and the local community, APANAJUCA designed a social innovation mechanism by which third parties could acquire land within the park for conservation and the collective public good.

The Coopelesca Scheme (see also Reference [25]) is a mechanism by which APANAJUCA finds and negotiates with interested third parties (usually not-for-profit organisations) that will acquire land within the park, place a covenant on the land and/or put it into a land trust for rehabilitation, conservation and environmental research. The APANAJUCA's role is to select appropriate land, negotiate a price with the current owner, find interested partners to acquire the land, manage the trust fund, manage the land and act as a bridging institution (between public and private) in the governance of the PA. The partner needs to be an organization with environmental and public interest objectives, for example, cooperatives, foundations, water associations and community development associations. These organisations tend to work in the public interest and, therefore, they receive support from the State.

The first partnership APANAJUCA developed was with the Rural Electrification Cooperative of San Carlos (Coopelesca). Together, the two organisations created a green savings trust, in which the associates of the cooperative-its 60,000 electricity consumers-starting in 2010 donate a small amount of their electricity bill to a fund. In 2014, the fund purchased over 1200 hectares of land in the park, approximately $8.5 \%$ of its total area. The benefits to Coopelesca include Carbon Neutral Certification and assurance of ongoing water supply for their hydroelectric power plants, which are located in the periphery of the park. Currently, APANAJUCA is looking for more land to acquire and place in Coopelesca's trust fund. It is also negotiating with other local cooperatives to establish similar schemes. This green land acquisition mechanism developed by APANAJUCA can be considered to be socially innovative in that it was conceived and enacted by a CBO with a genuine concern about 
sustainability. These mechanisms were developed through the creation of relations and instruments that were not in place before.

\subsection{AFAMAAR and the Nectandra Scheme}

According to our interviewees, members of AFAMAAR and other local people not in the organisation, the quality of water, the amount of water, and public health issues were the key elements of the discourse used by AFAMAAR to convince the community of Zarcero to contribute money for land acquisition. AFAMAAR started their campaign by organising local events, e.g., at which they would receive cattle or product donations to be auctioned later or being beneficiaries of the Catholic Church's annual parish fair. The profits of these activities were put in a fund in the name of the association. Unlike APANAJUCA, AFAMAAR is agreeable to being the owner of land, as most land they acquire is not within the park boundaries. With the money raised, they were able to buy several properties, totalling over 500 hectares. However, despite the good intentions of the community, raising money in this way was slow. In 2007, AFAMAAR members became acquainted with the Nectandra Institute, which offered them a green loan to purchase a property.

The Nectandra Institute, which was founded in 1999, is an NGO registered in California (USA) and is dedicated to the conservation of the Costa Rican cloud forest and to the stewardship of watershed ecosystems [63]. It is a registered Section 501(c)(3) organisation so that it is tax exempt and donations from US citizens are tax-deductible. The institute has a sister organisation in Costa Rica, Nectandra S.A., which manages the Nectandra Cloud Forest Garden, a 150-hectare property in the River Balsa sub-basin in the Municipality of San Ramon. In words of the interviewees, the garden was like an island rich in biodiversity, but surrounded by dairy pastures and ornamental plant farms. A watershed ecosystem vision was needed, and the institute started to promote the idea of green land acquisition to create biodiversity corridors. Coincidentally, many of the lands in question were water spring areas that also needed protection. Nectandra staff met with representatives of local water and sewage utilities (ASADAs) who, given that they lacked financial resources, urged that the properties that should be bought were those in which their water sources were located. The managers of the Nectandra Institute, in Costa Rica, designed a green loan mechanism, which they called an eco-loan fund. The eco-loan fund charges $0 \%$ interest and has a 10 to 15 year term of repayment. Instead of charging interest in monetary terms, they expect the borrower to undertake socio-ecological actions in the form of environmental workshops, educational programs in schools (especially in rural communities), and/or provide adequate ecological maintenance of the properties by restoring, protecting and monitoring the ecosystem services.

The interviewees, from Nectantra Institute and AFAMAAR, claimed that the mechanism is based on trust, and that there is a symbiotic relationship between the parties. Interested borrowers submit a loan proposal that includes an environmental management plan of the property, the financial history of the applicant organisation, and a repayment plan. Successful organisations not only receive the requested funding, but also technical assistance and coaching in green business. Their common interest is protection of ecosystems and ecosystem services. As of the date of the interviews (June 2019), there had never been a late repayment because of the shared understanding of the importance of making funds available to other applicants. As at 2019, 9 projects had been funded by Nectandra eco-loans in Costa Rica. The first eco-loan was given in 2007 for a property of 11 hectares, and by 2019 over 200 hectares had been acquired. AFAMAAR's eco-loan was implemented in 2009 to purchase the 100 hectare Ocotea farm. This was regarded as a major achievement by Nectandra and AFAMAAR's members (see Figure 3).

The Nectandra Scheme is an interesting, socially innovative financing mechanism, and a good example of how a social innovation fostered social-ecological transformation. Following Nectandra's example, AFAMAAR, is now financing green land acquisitions using their version of the eco-loan fund mechanism. The operating capital for AFAMAAR is generated by three means: (a) some of their properties receive payment for ecosystem services (PES) from the State; (b) some properties have 
been re-sold (with a covenant affixed) to other organisations or to the Municipality of Zarcero; and (c) earnings are put into profitable trusts or investment plans. The AFAMAAR has already financed two organisations and are in the process of co-financing a third one in conjunction with the Nectandra Institute. In total, AFAMAAR now owns over 700 hectares and has aided in the acquisition of another 50 hectares via the Nectandra Scheme. The interviewees recognise that AFAMAAR's aspirations have evolved, moving from ensuring water for agriculture and clean drinking water to a more integrated view of quality of life that includes biodiversity conservation and carbon reduction. Their current goal is to consolidate land in the park fringe in which their properties are located and, in that way, ensure both conservation of the water springs and the Juan-Castro-Blanco National Water Park.

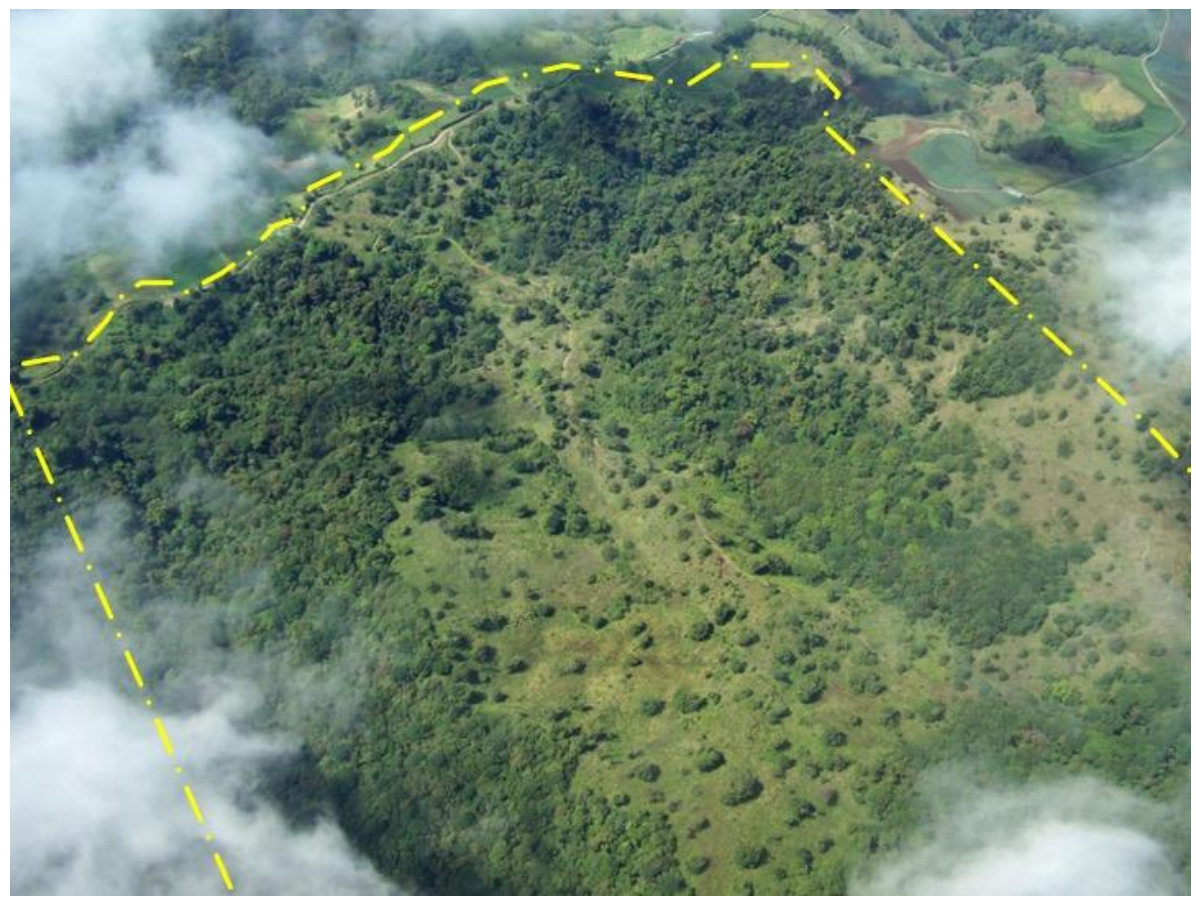

Figure 3. Aerial view of Ocotea farm. Source: Manrique Esquivel, Nectandra Institute.

\section{Challenges for Protected Area Governance and Environmental Governance}

The future of tropical forests, PAs, and their ecosystems services depends more than ever on: (a) more effective community involvement [64]; (b) harnessing of the synergies between environmental and social objectives [65,66]; (c) creative partnerships between public and private sectors [67]; and (d) effective management of human-modified landscapes [42]. These environmental governance strategies were all present in the governance of the Juan-Castro-Blanco National Water Park. The trigger for social innovation was the need for water provision (quality and quantity) for the communities surrounding the PA. This social need was aligned with the environmental objectives of nature conservation. Because nature conservation is not of exclusive interest only to States, public agencies (municipalities and management agencies), private sector organisations and community organisations agreed to develop relationships that will foster accomplishment of the social-ecological objectives. The mechanisms developed in these new relationships are intended to safeguard water sources and biodiversity by consolidating forest land. The more the communities self-organise and take responsibility for governance functions, the more likely it is that the forests will be protected [68]. However, this environmental governance process presents important challenges to conservation and land use management; it will require a conscious effort from all actors, because the goals are hard to accomplish $[42,65]$. 
In researching the Juan-Castro-Blanco National Water Park and the two socially innovative organisations that act to protect it, APANAJUCA and AFAMAAR, we identified some governance challenges that it faced and that PA management elsewhere may also encounter:

- The balance between productive and conservation land. In the context of Juan-Castro-Blanco, all forest land comprises high-quality soil desirable for crops and farming. The social-ecological characteristics of the system demand a balance between these land uses.

- Increased land prices. With agriculture and dairy farming being high profitable, and with payments for ecosystem services potentially also being profitable, the price of land increases over time. This makes it complex. It is expensive for farmers to expand operations, as well as for the CBOs to purchase land at commercial rates. It also makes it complicated for the State to expropriate the land at fair compensation levels.

- Diverse interests and goals. The more actors, the more interests there are to satisfy. Every actor in the governance of the Juan-Castro-Blanco not only plays a role, but also demands their needs to be met. It is not always easy to describe the roles and prioritize the interests in the governance dynamics. This means that there may be frictions between parties, for example, jealousy about hierarchies, tasks or accomplishments, leading to resentment and jeopardizing the ultimate goal of protected area and forest conservation.

- Getting consensus on a common sustainability framework. Each sector and actor involved in the environmental governance has their own definitions on sustainability, conservation and resource use which are based on their own epistemology and cosmology. For effective forest and PA governance, consensus is needed, otherwise there will be mistrust in the actions of the actors, and it will be difficult to develop alliances to foster social innovation.

- $\quad$ Outdated formal regulations and planning systems. New management and ownership models that result from the social innovation processes, and that are developed for more adaptive environmental governance are not usually included in existing legal structures. Until the public system assimilates the new forms of organizing, it might be problematic to reconcile the new practices with old legal frameworks, thus jeopardizing the effectiveness of the results.

\section{Applying a Social Innovation Lens to Green Land Acquisition}

The green grabbing literature primarily critiques those conservation organizations that prioritize the environment over local communities $[2,7,69,70]$. Even, when there is community involvement or community-based natural resource management, scholars of land grabbing often remain suspicious [3], especially because relying on local communities does not necessarily guarantee the conservation of forests and protected areas [69]; and because local actors may participate simply to gain personal benefit [71]. The development of new governance relationships is sometimes considered to be problematic because of the potential social harm that can be created [2]. Therefore, new socially innovative arrangements are needed, for example, the ones forged around the governance of the Juan-Castro-Blanco National Water Park which resulted in the acquisition of land for conversion of agriculture back into forest.

We argue that more research is needed to unravel the nuances of green grabbing. Some nuances have been mentioned in the literature, for example: Franco and Borras [12] recognize that the interconnections between environmental discourses, actors and aims-across global and local levels-are not unambiguous, requiring more analysis to understand governance processes; Corson et al. [70] concede that more examination of the governance system and logics that trigger and promote green land acquisition is needed; and Fairhead et al. [1] advocate that the aims and processes by which land is acquired, and the resultant outcomes, are intrinsically dependent on the context.

We showed that using a social innovation lens enables delving deeper into the governance of an SES and the social-ecological motives that promote green land acquisition. Zooming in to local and small-scale green land acquisition facilitates understanding the interconnections between actors, 
expectations, and, most importantly, the benefits and beneficiaries of social innovation. Any social innovation seeks the improvement of society, addresses social-ecological needs of communities, and empowers people [23]. Using a social innovation lens to examine APANAJUCA and AFAMAAR, and their green land acquisition mechanisms, revealed aspects of green land acquisition (notably their potential positive benefits) that have not been previously considered. It provided an opportunity to consider different aspects of green grabbing; allowing consideration of green land acquisition as potentially being positive in its aims and outcomes.

\section{Conclusions}

In this paper, we considered an interesting and unusual aspect that is under-researched in the literature on land acquisition, land grabbing and green grabbing: that not all green land acquisition is done by powerful outsiders and necessarily leads to dispossession. We focused on small-scale, community-led land acquisition for conservation purpose. We used the social-ecological systems and social innovation literature to consider the positive aims, methods and outcomes from green land acquisition undertaken by two local organisations, APANAJUCA and AFAMAAR, to support the Juan-Castro-Blanco National Water Park in Costa Rica. These two local organisations were interested in land consolidation for the conservation of the park and its forests and water resources. Using a social innovation lens, we examined the aims, motivations, actors, mechanisms, and expected outcomes from their green land acquisition activities. We consider that APANAJUCA and AFAMAAR, and their green land acquisition mechanisms, are good examples of social innovation. Their practices displayed the processes, products and outcomes of social innovation, and how social innovation impacts positively on local environmental governance and regional sustainable development. Our analysis showed that the relations forged and mechanisms used to protect the park and the forest created new models of environmental governance adding to the suite of potential tools and strategies to be used in protected area management. However, despite the success of the community-based organisations we considered, they still faced some challenges including: the balance between productive and conservation land; increasing land prices; diverse interests and goals; getting consensus on a common sustainability framework; and outdated formal regulations and planning systems. Our findings revealed that conservation can have many motives, but when synergies are developed, social innovation is likely to emerge.

We consider this paper to be a starting point in the exploration of the basis of community involvement in green land acquisition, and in the development of social innovation in the context of community-based natural resource management in a developing country. We encourage further research that would allow a comparison of results from different geographical and cultural settings. We suggest a focus on the changes in the governance of protected areas and forests prompted by social innovation and the ways rules are created and enacted.

Author Contributions: Conceptualization, K.C.-A. and F.V.; Methodology, K.C.-A.; Formal analysis, K.C.-A.; Investigation, K.C.-A.; Writing-original draft preparation, K.C.-A.; Writing-review and editing, K.C.-A., F.V.; Supervision, F.V.; Project administration, K.C.-A.; Funding acquisition, K.C.-A. All authors have read and agreed to the published version of the manuscript.

Funding: This research was supported by a scholarship from the Erasmus Mundus Action II, Peace Project 2013-2016; and by a staff development scholarship from the University of Costa Rica 2016-2020. The APC was funded by the University of Groningen.

Acknowledgments: We are grateful for the assistance provided by APANAJUCA, ACHAN, ADRHN, AFAMAR, Nectandra Institute, Water and Peace Biosphere Reserve, Coopelesca, ICE, the San Carlos Municipality, Zarcero Municipality, SINAC, and the School of Biology at the University of Costa Rica. Constanza Parra (University of Leuven) is also a supervisor of this $\mathrm{PhD}$ research and contributed to the overall research project.

Conflicts of Interest: The authors declare no conflict of interest. The funders had no role in the design of the study; in the collection, analyses, or interpretation of data; in the writing of the manuscript, or in the decision to publish the results. 


\section{References}

1. Fairhead, J.; Leach, M.; Scoones, I. Green Grabbing: A new appropriation of nature? J. Peasant Stud. 2012, 39, 237-261. [CrossRef]

2. Vanclay, F. Principles to gain a social licence to operate for green initiatives and biodiversity projects. Curr. Opin. Environ. Sustain. 2017, 29, 48-56. [CrossRef]

3. Benjaminsen, T.A.; Bryceson, I. Conservation, green/blue grabbing and accumulation by dispossession in Tanzania. J. Peasant Stud. 2012, 39, 335-355. [CrossRef]

4. Borras, S.M.; Franco, J.C.; Gómez, S.; Kay, C.; Spoor, M. Land grabbing in Latin America and the Caribbean. J. Peasant Stud. 2012, 39, 845-872. [CrossRef]

5. Vanclay, F. Project-induced displacement and resettlement: From impoverishment risks to an opportunity for development? Impact Assess. Proj. Apprais. 2017, 35, 3-21. [CrossRef]

6. Busscher, N.; Parra, C.; Vanclay, F. Environmental justice implications of land grabbing for industrial agriculture and forestry in Argentina. J. Environ. Plan. Manag. 2020, 63, 500-522. [CrossRef]

7. Busscher, N.; Parra, C.; Vanclay, F. Land grabbing within a protected area: The experience of local communities with conservation and forestry activities in Los Esteros del Iberá, Argentina. Land Use Policy 2018, 78, 572-582. [CrossRef]

8. Busscher, N.; Vanclay, F.; Parra, C. Reflections on how State-civil society collaborations play out in the context of land grabbing in Argentina. Land 2019, 8, 116. [CrossRef]

9. Castree, N. Neoliberalism and the biophysical environment: A synthesis and evaluation of the research. Environ. Soc. 2011, 1, 5-45. [CrossRef]

10. Vanclay, F.; Hanna, P. Conceptualizing company response to community protest: Principles to achieve a social license to operate. Land 2019, 8, 101. [CrossRef]

11. Zoomers, A. Globalisation and the foreignisation of space: Seven processes driving the current global land grab. J. Peasant Stud. 2010, 37, 429-447. [CrossRef]

12. Franco, J.C.; Borras, S.M. Grey areas in green grabbing: Subtle and indirect interconnections between climate change politics and land grabs and their implications for research. Land Use Policy 2019, 84, 192-199. [CrossRef]

13. Sikor, T. Tree plantations, politics of possession and the absence of land grabs in Vietnam. J. Peasant Stud. 2012, 39, 1077-1101. [CrossRef]

14. Dao, N. Rubber plantations in the Northwest: Rethinking the concept of land grabs in Vietnam. J. Peasant Stud. 2015, 42, 347-369. [CrossRef]

15. Pasaribu, S.I.; Vanclay, F.; Zhao, Y. Challenges to implementing socially-sustainable community development in oil palm and forestry operations in Indonesia. Land 2020, 9, 61. [CrossRef]

16. Holmes, G. What is a land grab? Exploring green grabs, conservation, and private protected areas in southern Chile. J. Peasant Stud. 2014, 41, 547-567. [CrossRef]

17. $\mathrm{Xu}, \mathrm{Y}$. Land grabbing by villagers? Insights from intimate land grabbing in the rise of industrial tree plantation sector in Guangxi, China. Geoforum 2018, 96, 141-149. [CrossRef]

18. Castro-Arce, K.; Vanclay, F. Transformative social innovation for sustainable rural development: An analytical framework to assist community-based initiatives. J. Rural Stud. 2020, 74, 45-54. [CrossRef]

19. Moulaert, F.; MacCallum, D.; Hillier, J. Social innovation: Intuition, precept, concept, theory and practice. In The International Handbook on Social Innovation: Collective Action, Social Learning and Transdisciplinary Research; Moulaert, F., MacCallum, D., Mehmood, A., Hamdouch, A., Eds.; Edward Elgar: Cheltenham, UK; Northampton, MA, USA, 2013; pp. 13-24. ISBN 1849809984.

20. Ravazzoli, E.; Valero, D.E. Social innovation: An instrument to achieve the sustainable development of communities. In Sustainable Cities and Communities; Leal Filho, W., Azul, A.M., Eds.; Springer: Cham, Switzerland, 2020; pp. 1-10. ISBN 978-3-319-71061-7.

21. Diepenmaat, H.; Kemp, R.; Velter, M. Why sustainable development requires societal innovation and cannot be achieved without this. Sustainability 2020, 12, 1270. [CrossRef]

22. Moore, M.L.; Westley, F. Surmountable chasms: Networks and social innovation for resilient systems. Ecol. Soc. 2011, 16, 5. [CrossRef] 
23. Mehmood, A.; Parra, C. Social innovation in an unsustainable world. In International Handbook on Social Innovation: Collective Action, Social Learning and Transdisciplinary Research; Moulaert, F., MacCallum, D., Eds.; Edward Elgar: Cheltenham, UK; Northampton, MA, USA, 2013; pp. 53-66.

24. Biggs, R.; Westley, F.; Carpenter, S. Navigating the back loop: Fostering social innovation and transformation in ecosystem management. Ecol. Soc. 2010, 15, 9. [CrossRef]

25. Castro-Arce, K.; Parra, C.; Vanclay, F. Social innovation, sustainability and the governance of protected areas: Revealing theory as it plays out in practice in Costa Rica. J. Environ. Plan. Manag. 2019, 62, 2255-2272. [CrossRef]

26. Peredo, A.M.; McLean, M.; Tremblay, C. Indigenous social innovation: What is distinctive? And a research agenda. In Handbook of Inclusive Innovation; George, G., Baker, T., Tracey, P., Joshi, H., Eds.; Edward Elgar: Cheltenham, UK; Northampton, MA, USA, 2019; pp. 107-128.

27. Melnykovych, M.; Nijnik, M.; Soloviy, I.; Nijnik, A.; Sarkki, S.; Bihun, Y. Social-ecological innovation in remote mountain areas: Adaptive responses of forest-dependent communities to the challenges of a changing world. Sci. Total Environ. 2018, 613, 894-906. [CrossRef] [PubMed]

28. Nijnik, M.; Secco, L.; Miller, D.; Melnykovych, M. Can social innovation make a difference to forest-dependent communities? For. Policy Econ. 2019, 100, 207-213. [CrossRef]

29. Kluvánková, T.; Brnkal'áková, S.; Špaček, M.; Slee, B.; Nijnik, M.; Valero, D.; Miller, D.; Bryce, R.; Kozová, M.; Polman, N.; et al. Understanding social innovation for the well-being of forest-dependent communities: A preliminary theoretical framework. For. Policy Econ. 2018, 97, 163-174. [CrossRef]

30. Sarkki, S.; Parpan, T.; Melnykovych, M.; Zahvoyska, L.; Derbal, J.; Voloshyna, N.; Nijnik, M. Beyond participation! Social innovations facilitating movement from authoritative state to participatory forest governance in Ukraine. Landsc. Ecol. 2019, 34, 1601-1618. [CrossRef]

31. Yin, R.K. Case Study Research: Design and Methods, 4th ed.; Sage: Thousand Oaks, CA, USA, 2009.

32. Evans, R. Case study method in sustainability research. In Researching Sustainability. A Guide to Social Science, Methods, Practice and Engagement; Franklin, A., Blyton, P., Eds.; Earthscan: New York, NY, USA, 2011; pp. 54-70.

33. Vanclay, F.; Baines, J.T.; Taylor, C.N. Principles for ethical research involving humans: Ethical professional practice in impact assessment Part I. Impact Assess. Proj. Apprais. 2013, 31, 243-253. [CrossRef]

34. Asamblea, L. Ley de Creación del Parque Nacional del Agua, Juan Castro Blanco; La Gaceta 110: Costa Rica, 1992.

35. SINAC. Plan General de Manejo del Parque Nacional del Agua Juan Castro Blanco; SINAC: San Carlos, Costa Rica, 2012.

36. Blanco Rojas, H. Áreas de recarga hídrica de la parte media-alta de las microcuencas Palo, Marín y San Rafaelito, San Carlos, Costa Rica. UNED Res. J. 2010, 2, 181-204. [CrossRef]

37. Costa Rica Named 'UN Champion of the Earth' for Pioneering Role in Fighting Climate Change. Available online: https://unfccc.int/news/costa-rica-named-un-champion-of-the-earth-for-pioneering-role-in-fightingclimate-chang (accessed on 17 February 2020).

38. Watts, J. Costa Rica Recognised for Biodiversity Protection. Available online: https://www.theguardian.com/ environment/2010/oct/25/costa-rica-biodiversity (accessed on 17 February 2020).

39. Leaders in Post-Paris Times-Achieving 100\% RE in Costa Rica. Available online: https://www. worldfuturecouncil.org/100-renewable-energy-costa-rica/ (accessed on 17 February 2020).

40. PEN. Estado de la Nación en Desarrollo Humano Sostenible; PEN: San José, CA, USA, 2018.

41. Poder, E. Reglamento a la Ley de Biodiversidad; La Gaceta 68: Costa Rica, 2008.

42. Gardner, T.A.; Barlow, J.; Chazdon, R.; Ewers, R.M.; Harvey, C.A.; Peres, C.A.; Sodhi, N.S. Prospects for tropical forest biodiversity in a human-modified world. Ecol. Lett. 2009, 12, 561-582. [CrossRef]

43. Gibbs, H.K.; Ruesch, A.S.; Achard, F.; Clayton, M.K.; Holmgren, P.; Ramankutty, N.; Foley, J.A. Tropical forests were the primary sources of new agricultural land in the 1980s and 1990s. Proc. Natl. Acad. Sci. USA 2010, 107, 16732-16737. [CrossRef]

44. Camino, R.D.; Villalobos, R.; Pierre, J.; Aymerich, M. Costa Rica Case Study Prepared for FAO as Part of the State of the World's Forests 2016 (SOFO). 2016. Available online: http://www.fao.org/3/a-c0180e.pdf (accessed on 17 February 2020).

45. The World Bank. Accounting Reveals that Costa Rica's Forest Wealth is Greater than Expected. 2016. Available online: https:/www.worldbank.org/en/news/feature/2016/05/31/accounting-reveals-that-costaricas-forest-wealth-is-greater-than-expected (accessed on 17 February 2020). 
46. González-Maya, J.F.; Víquez-R, L.R.; Belant, J.L.; Ceballos, G. Effectiveness of Protected Areas for Representing Species and Populations of Terrestrial Mammals in Costa Rica. PLoS ONE 2015, 10, e0124480. [CrossRef] [PubMed]

47. Shaver, I.; Chain-Guadarrama, A.; Cleary, K.A.; Sanfiorenzo, A.; Santiago-García, R.J.; Finegan, B.; Hormel, L.; Sibelet, N.; Vierling, L.A.; Bosque-Pérez, N.A.; et al. Coupled social and ecological outcomes of agricultural intensification in Costa Rica and the future of biodiversity conservation in tropical agricultural regions. Glob. Environ. Chang. 2015, 32, 74-86. [CrossRef]

48. Duffy, S.B.; Corson, M.S.; Grant, W.E. Simulating land-use decisions in the La Amistad Biosphere Reserve buffer zone in Costa Rica and Panama. Ecol. Modell. 2001, 140, 9-29. [CrossRef]

49. Moya, G. Proyecto Para Tomar Agua del Parque Juan Castro Blanco es Legal, Insisten Dirigentes de Acueducto. Available online: https://www.teletica.com/240636_proyecto-para-tomar-agua-del-parque-juancastro-blanco-es-legal-insisten-dirigentes-de-acueducto (accessed on 17 February 2020).

50. Delgado, M. Lamentable! Tala Ilegal Socava Parque Nacional del Agua Juan Castro Blanco. Available online: https://sancarlosdigital.com/lamentable-tala-ilegal-socava-parque-nacional-del-aguajuan-castro-blanco/ (accessed on 17 February 2020).

51. Delgado, M. Proyecto eólico se Desarrollaría en San Vicente y Parque Nacional del Agua Juan Castro Blanco. Available online: https://sancarlosdigital.com/proyecto-eolico-se-desarrollaria-en-san-vicente-y-parquenacional-del-agua-juan-castro-blanco/ (accessed on 17 February 2020).

52. Miranda, H. Depredadores Están “Vaciando" de Especies Los Bosques Protegidos. Available online: http://semanariouniversidad.ucr.cr/pais/depredadores-estan-vaciando-especies-los-bosques-protegidos/ (accessed on 17 February 2020).

53. Delgado, M. Sala Constitucional Ratifica: PNJCB es de Los Sancarleños. Available online: https://sancarlosdigital.com/sala-constitucional-ratifica-pnjcb-es-de-los-sancarlenos (accessed on 17 February 2020).

54. Asamblea, L. Ley de Aguas—y Modificaciones; SINALEVI: Costa Rica, 1972; pp. 1-65.

55. Asamblea, L. Ley Forestal y Modificaciones; La Gaceta 172: Costa Rica, 1996; pp. 1-81.

56. Berkes, F.; Arce-lbarra, M.; Armitage, D.; Charles, A.; Loucks, L.; Makino, M.; Satria, A.; Seixas, C.; Abraham, J.; Berdej, S. Analysis of Social-Ecological Systems for Community Conservation; Community Conservation Research Network: Halifax, NS, Canada, 2016.

57. Ostrom, E. A general framework for analyzing sustainability of social-ecological systems. Science 2009, 325, 419-422. [CrossRef]

58. Liu, J.; Dietz, T.; Carpenter, S.R.; Alberti, M.; Folke, C.; Moran, E.; Pell, A.N.; Deadman, P.; Kratz, T.; Lubchenco, J.; et al. Complexity of coupled human and natural systems. Science 2007, 317, 1513-1516. [CrossRef]

59. Cumming, G.S.; Allen, C.R. Protected areas as social-ecological systems: Perspectives from resilience and social-ecological systems theory. Ecol. Appl. 2017, 27, 1709-1717. [CrossRef]

60. Brondizio, E.S.; Ostrom, E.; Young, O.R. Connectivity and the governance of multilevel social-ecological systems: The role of social capital. Annu. Rev. Environ. Resour. 2009, 34, 253-278. [CrossRef]

61. McGinnis, M.D.; Ostrom, E. Social-ecological system framework: Initial changes and continuing challenges. Ecol. Soc. 2014, 19, 30. [CrossRef]

62. Polman, N.; Kluvánková, A.T.; Gežik, V.; Špaček, M.; Brnkaláková, S.; Valero, D.; Bryce, R.; Alkhaled, S.; Secco, L.; Kozova, M.; et al. Report D2.1 Transdisciplinary understanding of SI in MRAs. 2017. Available online: https://ec.europa.eu/research/participants/documents/downloadPublic?documentIds= 080166e5b572f410\&appId=PPGMS (accessed on 17 February 2020).

63. Nectandra Institute: About Us-Organization \& Mission. Available online: https://www.nectandra.org/org/ about.php (accessed on 17 February 2020).

64. Grazia, B.F. Rosemary Hill Governance for the conservation of nature. In Protected Area Governance and Management; Graeme, L.W., Michael, L., Eds.; ANU Press: Canberra, Australia, 2015; pp. 169-206.

65. Sarkki, S.; Rantala, L.; Karjalainen, T.P. Local people and protected areas: Identifying problems, potential solutions and further research questions. Int. J. Environ. Sustain. Dev. 2015, 14, 299. [CrossRef]

66. Heslinga, J.; Groote, P.; Vanclay, F. Towards resilient regions: Policy recommendations for stimulating synergy between tourism and landscape. Land 2020, 9, 44. [CrossRef] 
67. Pringle, R.M. Upgrading protected areas to conserve wild biodiversity. Nature 2017, 546, 91-99. [CrossRef] [PubMed]

68. Andersson, K.; Benavides, J.P.; León, R. Institutional diversity and local forest governance. Environ. Sci. Policy 2014, 36, 61-72. [CrossRef]

69. Kopnina, H. Revisiting the Lorax complex: Deep ecology and biophilia in cross-cultural perspective. Environ. Sociol. 2015, 1, 315-324. [CrossRef]

70. Corson, C.; MacDonald, K.I.; Neimark, B. Grabbing green: Markets, environmental governance and the materialization of natural capital. Hum. Geogr. 2013, 6, 1-15. [CrossRef]

71. Green, K.E.; Adams, W.M. Green grabbing and the dynamics of local-level engagement with neoliberalization in Tanzania's wildlife management areas. J. Peasant Stud. 2015, 42, 97-117. [CrossRef]

(C) 2020 by the authors. Licensee MDPI, Basel, Switzerland. This article is an open access article distributed under the terms and conditions of the Creative Commons Attribution (CC BY) license (http://creativecommons.org/licenses/by/4.0/). 